\title{
Correction to: Some theoretical insights into the hologenome theory of evolution and the role of microbes in speciation
}

\author{
Adrian Stencel $^{1} \cdot$ Dominika M. Wloch-Salamon $^{2}$
}

Published online: 21 September 2018

(c) The Author(s) 2018

\section{Correction to: Theory in Biosciences https://doi.org/10.1007/s12064-018-0268-3}

The original version of this article unfortunately contained a mistake.

The entry Suárez, J. Symbiosis (2018). https://doi. org/10.1007/s13199-018-0556-1 was missing in the reference list.

The corrected reference list is given below.

Open Access This article is distributed under the terms of the Creative Commons Attribution 4.0 International License (http://creativeco mmons.org/licenses/by/4.0/), which permits unrestricted use, distribution, and reproduction in any medium, provided you give appropriate credit to the original author(s) and the source, provide a link to the Creative Commons license, and indicate if changes were made.

\section{References}

Baumann P (2005) Biology of bacteriocyte-associated endosymbionts of plant sap-sucking insects. Ann Rev Microbiol 59:155-189

Brandvain Y, Wade MJ (2005) The functional transfer of genes from the mitochondria to the nucleus: the effects of selection, mutation, population size and rate of self-fertilization. Genetics 182(4):1129-1139

Brucker RM, Bordenstein SR (2012) Speciation by symbiosis. Trends Ecol Evol 27:443-451

Brucker RM, Bordenstein SR (2013) The hologenomic basis of speciation: gut bacteria cause hybrid lethality in the genus Nasonia. Science 341:667-669

The original article can be found online at https://doi.org/10.1007/ s12064-018-0268-3.

Adrian Stencel

adstencel@gmail.com

1 Faculty of Philosophy, Jagiellonian University, ul. Gołębia 24, 31-007 Kraków, Poland

2 Institute of Environmental Sciences, Jagiellonian University, Gronostajowa 7, 30-387 Kraków, Poland
Chandler J, Turelli M (2014) Comment on "The hologenomic basis of speciation: gut bacteria cause hybrid lethality in the genus Nasonia". Science 345(6200): 1011

Coyne JA, Orr HA (2004) Speciation. Sinauer Associates, Sunderland

Dawkins R (1976) The selfish gene. Oxford University Press, Oxford

Dawkins R (1982) The extended phenotype. W. H. Freeman, Oxford

Dobzhansky T (1937) Genetics and the origin of species. Columbia University Press, New York

Douglas AE, Werren JH (2016) Holes in the hologenome: why hostmicrobe symbioses are not holobionts. mBio 7(2):e02099

Gibson R, Atkinson R, Gordon J (2010) The biology of vestimentiferan tubeworms. Oceanogr Mar Biol Annu Rev 48:213-266

Gilbert SF, Sapp J, Tauber AI (2012) A symbiotic view of life: we have never been individuals. Q Rev Biol 87:325-341

Godfrey-Smith P (2009) Darwinian populations and natural selection. Oxford University Press, Oxford

Godfrey-Smith P (2012) Darwinian individuals. In: Bouchard F, Huneman P (eds) From groups to individuals: perspectives on biological associations and emerging individuality. MIT Press, Cambridge, pp 17-36

Godfrey-Smith P (2015) Reproduction, symbiosis, and the eukaryotic cell. Peter Godfrey-Smith. Proc Natl Acad Sci 112(33):10120-10125

Godoy-Vitorino F, Leal SJ, Diaz WA, Rosales J, Goldfarb KC, GarciaAmado MA, Michelangeli F, Brodie EL, Dominguez-Bello MG (2012) Differences in crop bacterial community structure between hoatzins from different geographical locations. Res Microbiol 163:211-220

Griesemer J (2001) The units of evolutionary transition. Selection 1:67-80

Harrison MJ (2005) Signaling in the arbuscular mycorrhizal symbiosis. Annu Rev Microbiol 59:19-42

Hooper LV, Littman DR, Macpherson AJ (2012) Interactions between the microbiota and the immune system. Science 336:1268-1273

Hosokawa T, Kikuchi Y, Nikoh N, Shimada M, Fukatsu T (2006) Strict host-symbiont cospeciation and reductive genome evolution in insect gut bacteria. PLoS Biol 4:1841-1851

Hull DL (1980) Individuality and selection. Ann Rev Ecol Syst 11:311-332

Hutter T, Gimbert Carine, Bouchard Frédéric, Lapointe FrançoisJoseph (2015) Being human is a gut feeling. Microbiome 3:9

Klose J, Polz MF, Wagner M, Schimak MP, Gollner S, Bright M (2015) Endosymbionts escape dead hydrothermal vent tubeworms to enrich the free-living population. Proc Natl Acad Sci USA 112(36):11300-11305

Koonin EV, Wolf YI (2012) Evolution of microbes and viruses: a paradigm shift in evolutionary biology? Front Cell Infect Microbiol $2: 119$ 
Laudan L (1981) A confutation of convergent realism. Philos Sci 48(1):19-49

Lewontin RC (1970) The units of selection. Ann Rev Ecol Syst 1:1-18

Ley RE, Peterson DA, Gordon JI (2006) Ecological and evolutionary forces shaping microbial diversity in the human intestine. Cell 124:837-848

Linnenbrink M, Wang J, Hardouin EA, Kunzel S, Metzler D, Baines JF (2013) The role of biogeography in shaping diversity of the intestinal microbiota in house mice. Mol Ecol 22:1904-1916

Margulis L (1993) Origins of species: acquired genomes and individuality. BioSystems 31:121-125

Mazmanian S, Liu C, Tzianabos A, Kasper D (2005) An immunomodulatory molecule of symbiotic bacteria directs maturation of the host immune system. Cell 122:107-118

Moran NA, Sloan DB (2015) The hologenome concept: helpful or hollow? PLoS Biol 13(12):e1002311

O'Malley MA, Dupre J (2007) Size doesn't matter: towards a more inclusive philosophy of biology. Biol Philos 22:155-191

Oh PL, Benson AK, Peterson DA, Patil PB, Moriyama EN, Roos S, Walter J (2010) Diversification of the gut symbiont Lactobacillus reuteri as a result of host-driven evolution. ISME J 4:377-387

Okasha S (2006) Evolution and the levels of selection. Oxford University Press, Oxford

Pradeu T (2010) What is an organism? an immunological answer. Hist Philos Life Sci 32:247-268

Pradeu T (2011) A mixed self: the role of symbiosis in development. Biol Theory 6:80-88

Pradeu T (2016) Organisms or biological individuals? combining physiological and evolutionary individuality. Special issue on biological individuality (T. Pradeu, ed.). Biol Philos 31(6):797-817

Queller DC, Strasmann JE (2009) Beyond society: the evolution of organismality. Philos Trans R Soc B364:3143-3155

Queller DC, Strasmann JE (2010) The social organism: congresses, parties, and committees. Evolution 64(3):606-615

Queller D, Strasmann J (2016) Problems of multi-species organisms: endosymbionts to holobionts. Biol Philos 31(6):855-873

Rees T, Bosch T, Douglas AE (2018) How the microbiome challenges our concept of self. PLoS Biol 16(2):e2005358
Rose MR, Oakley TH (2007) The new biology: beyond the modern synthesis. Biol Direct 2:30

Sender R, Fuchs S, Milo R (2016) Revised estimates for the number of human and bacteria cells in the body. PLoS Biol 14(8):e1002533

Singh RK, Chang H-W, Yan D, Lee KM, Ucmak D, Wong K, Abrouk M, Farahnik B, Nakamura M, Zhu TH, Bhutani T, Liao W (2017) Influence of diet on the gut microbiome and implications for human health. J Transl Med 15:73

Skillings DJ (2016) Holobionts and the ecology of organisms-multispecies communities or integrated individuals? Biol Philos 31:875

Stencel A (2016) The relativity of darwinian populations and the ecology of endosymbiosis. Biol Philos 31:619-637

Stencel A, Proszewska A (2017) How research on microbiomes is changing biology: a discussion on the concept of the organism. Found Sci. https://doi.org/10.1007/s10699-017-9543-x

Suárez J (2018) Symbiosis. https://doi.org/10.1007/s13199-018-0556-1

Theis KR, Dheilly NM, Klassen JL, Brucker RM, Baines JF, Bosch TCG, Cryan JF, Gilbert SF, Goodnight CJ, Lloyd EA, Sapp J, Vandenkoornhuyse P, Zilber-Rosenberg I, Rosenberg E, Bordenstein SR (2016) Getting the hologenome concept right: an eco-evolutionary framework for hosts and their microbiomes. mSystems 1(2):e00028-16

Vuong HE, Yano JM, Fung TC, Hsiao EY (2017) The microbiome and host behavior. Annu Rev Neurosci 40:21-49

Wang B, Qiu Y-L (2006) Phylogenetic distribution and evolution of mycorrhizas in land plants. Mycorrhiza 16:299-363

Wang JK, Steck B, Turner B et al (2015) Analysis of intestinal microbiota in hybrid house mice reveals evolutionary divergence in a vertebrate hologenome. Nat Commun 6:6440

Yatsunenko T, Rey FE, Manary MJ, Trehan I, Dominguez-Bello MG, Contreras M, Magris M, Hidalgo G, Baldassano RN, Anokhin AP, Heath AC, Warner B, Reeder J, Kuczynski J, Caporaso JG, Lozupone CA, Lauber JC, Clemente D (2012) Human gut microbiome viewed across age and geography and geography. Nature 486:222-227

Zilber-Rosenberg I, Rosenberg E (2008) Role of microorganisms in the evolution of animals and plants: the hologenome theory of evolution. FEMS Microbiol Rev 32:723-735 